\title{
Analysis Determinants of Labor Supply for Married Woman in West Sumatra
}

\author{
Adi Warman ${ }^{1}$, Idris ${ }^{2}$, Sri Ulfa Sentosa ${ }^{3}$ \\ ${ }^{1}$ Universitas Negeri Padang (UNP), west Sumatera, Indonesia, $\$ (e-mail) adi.warman50@yahoo.co.id \\ ${ }^{2}$ Universitas Negeri Padang (UNP), west Sumatera, Indonesia, $\bowtie$ (e-mail) idris_unp@yahoo.co.id \\ ${ }^{3}$ Universitas Negeri Padang (UNP), west Sumatera, Indonesia, $₫$ (e-mail)sriulfasentosa66@gmail.com
}

\begin{abstract}
This research aims to analyze and determine the effect of wages, husband's income, age, number of dependents, and education on labor supply of married women in West Sumatra partially or simultaneously. This research used the data organized as cross section with the number of data 1.068 people. The data in this research were obtained from Survey of the national workforce (Sakernas) in 2016 by Central Bureau of Statistics (BPS) in West Sumatera Province. Model of data analysis used Ordinary Least Square (OLS) method. The results of this study concluded that wages, husband's income, age, number of dependents and education have significant effect on Labor supply of married women in West Sumatra. Further, the increasing of wages, decreasing of husband's income, younger age, fewer dependents and higher education influences labor supply of married women.
\end{abstract}

Keywords: labor supply, married women and workers.

\section{Introduction}

In line with growing economy in Indonesia, the participation rate of labor, especially the number of women' labor, has increased. It is not caused accidentally, but it is caused that the role of women in the labor market is quite good. Women as one of the human resources in the labor market especially in Indonesia has an important contribution, in that the number of women who offer themselves to work sufficiently big.

Entry of women labor into various sectors indicates that there is no restriction in working for women. Many of jobs were formerly only done by men but now that can be done by women. These changes occur as a result of changes in the social economic environment.

The phenomenon of increasing labor for married women workers also occur in a city of Indonesia precisely in West Sumatra. Based on data from BPS, it can be known that the number of married women workers in West Sumatra from 2011 to 2015 have increased from year to year both in its nominal and in its development. In 2011 the number of married women workers in West Sumatra reached 20,627 persons. Then they happened increasing in 2012 to 20,847 or increasing $1.07 \%$. This condition continues to increase until 2015 to 21,395 persons or an increasing $1.29 \%$. This increasing in 2015 is the largest increasing from 2011-2015.

The increasing number of married women labor is not apart from the factors expected to influence it. According to Budiman (2005), Blau (2016), Carlson (2012), Denilson (2014), Mincer (2016), Minh (2008), Nilakusumawati (2010), Zehra (2008), there are several factors causing married women to enter in the labor market. These factors include wages, income other than wages (husband's income), age, number of dependents, and education. Increased wages will encourage married women to continue working because wages are a reward for the sacrifices done by married women.

Then, According Damayanti (2011), Danim (2003), Eliana (2007), Laswell (2005), Mincer (2016), dan Sumartoyo (2002), when income other than wages increases as an increasing of wages or income husbands, its condition will exactly cause a lack of working hours for married women because family 
income has increased. Getting on age causes the desire of married women to work becomes less because it can cause the decreased physical ability of a person (Suparmoko (2012), Subri (2003), Denilson (2014), Bowen (2004), Arfida (2003). The greater of the number for family dependents can cause the excelsior of working hours for married women. This situation is caused by the expenditure for family needs will be gone high so that income should also be added by increasing the number of working hours. Higher education can encourage married women to work because married women with high education will find it easier to get a better job (Damayanti (2011), Danim (2003), Subri (2003), Denilson (2014), Bowen (2004).

The high increasing of labor supply for married women in West Sumatera is influenced by several factors. These factors are wages, husband's income, age, number of dependents and education. According to central bureau of statistics data (BPS) in West Sumatra, wages should have increased in 2015 but actually decreased from the previous year. Wages in 2014 increased by $9.81 \%$ while in 2015 onli increased by $7.90 \%$. This shows the discrepancy between theory and reality in variables of this research. In 2015 the average of husbands' income should be going decreased because married women working in West Sumatra increased but it showed an increase. Once again this condition also shows the phenomenon in this research. In 2015 the average age of married women working in West Sumatra have a decreasing into 39.9 years from the previous year reached 40.6 years. This shows the absence of phenomenon in the research which states that the decline in age affects the decreasing ability of the working hours of married women. In 2013 and 2014 the average number of dependents married women work as many as 4 persons and increased to 6 persons in 2015. Thus, it can be expected that an increasing number of married women work in West Sumatra by the increasing number of dependents for married women workers. In 2015 the average of length school for married women working in West Sumatra reaches 13 years. This condition has increased the number of married women working in West Sumatra.

Offering labor is the amount of labor that can be made available at every possible wage in a given period of time. In the classical theory of human resources (workers) are individuals who are free to take decisions to work or not. Even workers are also free to set the number of working hours they want. This theory is based on the theory of consumer, where each individual aims to maximize the satisfaction with the constraints faced. According to Becker (1976: 07), individual satisfaction can be obtained through consumption or enjoying leisure (leisure). While the constraints faced by individuals are the level of income and time. Working as a controversy of leisure causes suffering, so people only want to do if getting compensation in the form of income, so the solution of this individual problem is the number of hours worked to be offered at the wage and price levels desired.

Based on the theory of utility (satisfaction) in which a consumer will maximize its satisfaction by consuming goods or services. In general the concept is formulated in the equation (Borjas, 2013: 72):

$$
\mathrm{U}=\mathrm{F}\left(\mathrm{X}_{1}, \mathrm{X}_{2}\right)
$$

From the theory "utility", consumers use goods $\mathrm{X} 1, \mathrm{X} 2$ to get maximum satisfaction. Item $\mathrm{X} 1$ is purchased with revenue earned from the time devoted to work. In allocating the individual time is faced in two choices of working and not working to enjoy his spare time. Based on the utility function above, then simply the relationship is written as follows (Borjas, 2013: 72):

$$
\operatorname{Max} \mathrm{U}=\mathrm{F}(\mathrm{Y}, \mathrm{L})
$$

Where: $\mathrm{Y}=$ income used to buy goods

$$
\mathrm{L}=\text { free time }
$$

Becker proposes that households have certain production functions expressed by $\mathrm{Zi}=\mathrm{fi}(\mathrm{Xi}, \mathrm{Ti})$. Here the item $\mathrm{Z}$ is determined by input in the form of the item vector $\mathrm{Xi}$, and the time vector Ti. Using this concept, household activities are viewed as an economic unit that performs two activities simultaneously, namely production activities and consumption activities. The function of utility that 
will maximize household is to combine various items of $\mathrm{Zi}$ which can be expressed by $\mathrm{U}=\mathrm{U}(\mathrm{Zi}, \ldots$, $\mathrm{Zm})$. Since $\mathrm{Zi}=\mathrm{fi}(\mathrm{Xi}, \mathrm{Ti})$, then $\mathrm{U}=(\mathrm{Xi}, \ldots, \mathrm{Xm}, \mathrm{Ti}, \ldots, \mathrm{Tm})$. In maximizing the function of utility, households are confronted with budget constraints $\mathrm{g}(\mathrm{Zi}, \ldots, \mathrm{Zm})=\mathrm{Z}$, where $\mathrm{g}$ is the household expenditure function and $\mathrm{Z}$ is the maximum of household resources.

The household satisfaction function of Becker (1976) is:

$$
\mathrm{U}=\mathrm{U}\left(\mathrm{Z}_{1}, \mathrm{Z}_{2}, \ldots, \mathrm{Zm}_{\mathrm{m}}\right)
$$

Where: $\mathrm{Zi}=$ the product produced by the household $(\mathrm{i}=1,2, \ldots \mathrm{m})$

Household products are a function of:

$$
\mathrm{Zi}=\mathrm{fi}(\mathrm{Xi}, \mathrm{Ti})
$$

Where: $\mathrm{X} i=\mathrm{i}$ goods and services purchased in the market

$\mathrm{Ti}=$ time used to produce an item $\mathrm{Z}$ to- $\mathrm{i}$

In maximizing its satisfaction, households are constrained by budget constraints and time constraints seen in the following two equations:

$$
\begin{aligned}
& \sum_{1}^{m} P_{i} X_{i}=I=V+T w W \\
& \sum_{1}^{m} T_{i}=T C=T-T w
\end{aligned}
$$

Where: $\mathrm{Pi}=$ the price of the goods and services purchased at the market

$\mathrm{Tw}=$ time allocated to work

$\mathrm{W}=$ wages

$\mathrm{V}=$ income other than wages

$\mathrm{Tc}=$ the amount of time consumed

$\mathrm{T}=$ amount of time available

$\mathrm{I}=$ household income

Previous research related to the this research are that Mincer (2016) found that husbands' working hours, wages and incomes have a significant effect on the participation of married women workers in the United States. Blau (2016) in his study concluded that real wages, working hours, education, and income of husband encourage married women to work in the United States. Carlson (2012) concluded that the variable income of husband, education and the number of dependents have a significant effect on the decision to work for housewives while the variable age has no significant effect on employment decisions for housewives in Scotland. The subsequent research was conducted by Denilson (2014). His research concluded that wages, incomes of husbands, the number of family dependents, age, and education had a significant effect on the supply of female labor. Husband's income has the greatest effect on the supply of women married workers in Ireland. Minh (2008) concluded that education, age and income of husband have significant effect to decision of married woman to work in Vietnam while the age and number of dependents have no significant effect on the decision of women who are married to work in Vietnam. Then Parkinson (2012) who found that wages, education, number of children, household expenditure had a significant effect on the supply of married female workers in South Korea while husband and age earnings have no significant effect on the supply of married female workers in South Korea.

\section{Methods}

Data of all variables in this research were obtained from survey of national workforce data by central bureau of statistics in West Sumatera in 2016. As stated in the theoretical study that the 
equality of labor supply for married women is influenced by wages, husband's income, age, number of dependents and education in the form of non linear equations. Where the equation is:

$$
Y=X_{1} \beta_{1}+X_{2} \beta_{2}+X_{3} \beta_{3}+X_{4} \beta_{4}+X_{5} \beta_{5}^{\mu}
$$

To obtain the elasticity coefficient of equation 8 , then this equation is transformed in log form as follows:

$\log Y=\beta_{0}+\beta_{1} \log X_{1}+\beta_{2} \log X_{2}+\beta_{3} \log X_{3}+\beta_{4} \log X_{4}$

$$
+\beta_{5} \log X_{5}+\mu
$$

Where:

$\mathrm{Y}=$ labor supply for married women, $\mathrm{X} 1=$ wage, $\mathrm{X} 2$ = husband income, $\mathrm{X} 3=$ age,

$\mathrm{X} 4=$ total dependent, $\mathrm{X} 5=$ education, $\mu=$ error term.

To ensure the results of the regression estimation using the OLS method above fulfill the assumption of Best Linear Unbiased Estimator (BLUE), it is necessary to test the classical assumption. The classical assumption test in this research is a) Normality test with Jarque-Bera method, b) Multicolinearity test with Variance Inflation Factor (VIF) method, and c) Heteroscedasticity test by Glejser method.

\section{Results}

Based on data processing and analyzing by using program Eviews 8, obtained the results of data processing for various test and analysis model as follows:

\section{a. Normality test}

The results of normality test data in this research can be seen in Table 1. From the results of normality test with using Jarque Bera (JB) method shows that JB Probability value $(0.564739)>0.05$. Therefore JB value $>0.05$ so it can be concluded that distribution of variable data in this research have normal distribution. Normal distribution data means that data centered on the data center is average, median and model.

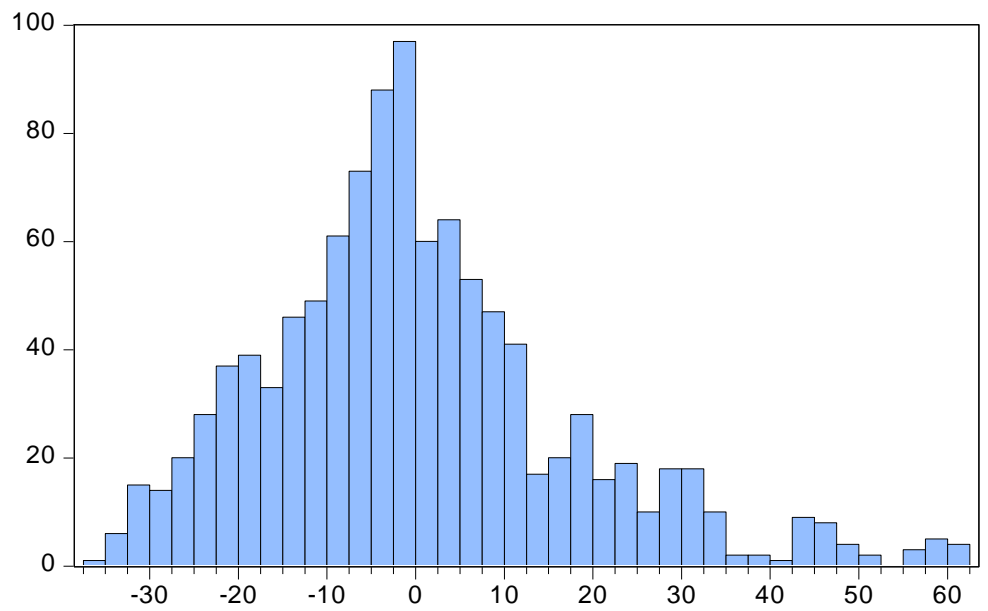

\begin{tabular}{|ll|}
\hline \multicolumn{2}{|l|}{ Series: Residuals } \\
Sample 1 1068 \\
Observations & 1068 \\
Mean & $-3.44 \mathrm{e}-15$ \\
Median & -2.022402 \\
Maximum & 62.08173 \\
Minimum & -35.12677 \\
Std. Dev. & 17.40328 \\
Skewness & 0.797466 \\
Kurtosis & 3.969532 \\
& \\
Jarque-Bera & 2.253271 \\
Probability & 0.564739 \\
\hline
\end{tabular}

Figure 1 Test of Data Normality with Jarque-Bera Method Source: results of data processing with Eviews $8, \mathrm{n}=1.068 \alpha=0.05$

\section{b. Multicollinearity Test}

From the multicollinearity test in Table 2, it is can seen that the Centered VIF values of all variables $(\mathrm{X} 1, \mathrm{X} 2, \mathrm{X} 3, \mathrm{X} 4$, and $\mathrm{X} 5)<5$. Therefore it can be concluded that there is no strong correlation between the independent variables. 
Table 2 Multicollinearity Test Result with VIF Method Variance Inflation Factors

Date: 04/07/18 Time: 03:16

Sample: 11068

Included observations: 602

\begin{tabular}{cccc}
\hline \hline Variable & $\begin{array}{c}\text { Coefficient } \\
\text { Variance }\end{array}$ & $\begin{array}{c}\text { Uncentered } \\
\text { VIF }\end{array}$ & $\begin{array}{c}\text { Centered } \\
\text { VIF }\end{array}$ \\
\hline \hline C & 0.376982 & 804.4708 & NA \\
LOG $(X 1)$ & 0.000683 & 286.8155 & 1.577541 \\
LOG $(X 2)$ & 0.001001 & 442.3910 & 1.349944 \\
LOG $(X 3)$ & 0.017998 & 536.3762 & 1.055258 \\
LOG $(X 4)$ & 0.002380 & 1.943750 & 1.014392 \\
LOG $(X 5)$ & 0.005377 & 67.54860 & 1.493821 \\
\hline \hline
\end{tabular}

Source: results of data processing with Eviews 8, $\mathrm{n}=1.068$

c. Heterocedasticity Test

From the result of heteroscedasticity test with Glejser method above shows that the probability value $\mathrm{F}(0.7283)$ all variables $>0.05$. It is caused of probability value $\mathrm{F}>0.05$. so, it can be concluded that there is no problem of heteroskedasticity in this research.

Table 3 Heterocedasticity Test Result with Glejser Method Heteroskedasticity Test: Glejser

\begin{tabular}{llll}
\hline \hline F-statistic & 0.982722 & Prob. F(5,596) & 0.7283 \\
Obs*R-squared & 93.17341 & Prob. Chi-Square(5) & 0.0000 \\
Scaled explained SS & 116.7775 & Prob. Chi-Square(5) & 0.0000 \\
\hline \hline
\end{tabular}

Source: results of data processing with Eviews 6, $\mathrm{n}=1.068 \alpha=0.05$

d. Results of Estimation of Multiple Regression Model for Labor Supply of Married Women in West Sumatra

Table 4 shows estimates of the effect of wages, husband's income, age, number of dependents, and education on the supply labor of married women in West Sumatra. From the estimation results have been obtained model equations supply labor of married women as follows:

$\log Y=1.674022+0.240078 \log X_{1}-0.389295 \log X_{2}-0.292568 \log X_{3}$

$$
+0.644227 \log X_{4}+0.927882 \log X_{5}
$$

Based on the results of the above analysis, it can be concluded that if the wage, income of husband, age, the number of dependents, and education value is zero then the value of supply labor for married women in West Sumatra is 47 hours / month. The R-squared value of the supply labor for married women equation is 0.559336 . This shows that the contribution of wage variable, husband's income, age, number of dependents, and education on supply labor for married women in West Sumatera is 55.93 percent while the rest of 44.07 percent is influenced by other variables not included in the equation of supply labor for married women Sumatra.

Wages have a significant positive effect on the supply labor for married women in West Sumatra. This can be seen from the probability value of wages $(\mathrm{X} 1)<0.05$. The significant effect of wages on the supply labor of married women indicates that the supply labor of married women is influenced by wages. This condition is caused by increased wages will encourage workers to enter the workforce because wages are a reward from workers to reduce leisure time and wage increases will promise happening in an increasing of income. Increased income will increase people welfare. Further the workers especially women in this research will enter workforce if there is a promising wage. Thus, 
wage increases will increase labor supply. Conversely, lower wages will become the lower interest of workers to enter the workforce because the rewards earned do not promise an increase in welfare for workers. Therefore, the decreasing wages will decrease labor supply especially married women.

Table 4 Results of Estimation of Multiple Regression Model for Labor Supply of Married Women in West Sumatra

\begin{tabular}{|c|c|c|c|c|}
\hline $\begin{array}{l}\text { Dependent Variable: } \\
\text { Method: Least Squar } \\
\text { Date: 04/07/18 Time } \\
\text { Sample (adjusted): } 4 \\
\text { Included observation }\end{array}$ & $\begin{array}{l}D G(Y) \\
3: 16 \\
68 \\
602 \text { after adj }\end{array}$ & stments & & \\
\hline Variable & Coefficient & Std. Error & $\mathrm{t}$-Statistic & Prob. \\
\hline $\mathrm{C}$ & 1.674022 & 0.613989 & 2.726469 & 0.0066 \\
\hline LOG(X1) & 0.240078 & 0.026136 & 9.185590 & 0.0000 \\
\hline $\operatorname{LOG}(X 2)$ & -0.389295 & 0.121449 & -3.205417 & 0.0024 \\
\hline $\operatorname{LOG}(X 3)$ & -0.292568 & 0.134155 & -2.180825 & 0.0296 \\
\hline $\operatorname{LOG}(X 4)$ & 0.644227 & 0.084454 & 7.628181 & 0.0000 \\
\hline LOG(X5) & 0.927882 & 0.143959 & 6.445475 & 0.0000 \\
\hline R-squared & 0.559336 & Mean depen & ent var & 3.532057 \\
\hline Adjusted R-squared & 0.552284 & S.D. depend & th var & 0.576871 \\
\hline S.E. of regression & 0.531133 & Akaike info & iterion & 1.582310 \\
\hline Sum squared resid & 168.1332 & Schwarz crit & ion & 1.626166 \\
\hline Log likelihood & -470.2752 & Hannan-Qu & n criter. & 1.599380 \\
\hline F-statistic & 22.59276 & Durbin-Wat & n stat & 1.976241 \\
\hline Prob(F-statistic) & 0.000000 & & & \\
\hline
\end{tabular}

Source: Results of data processing with Eviews 6, $\mathrm{n}=1.068 \alpha=0.05$

Husband's income has a significant negative effect on the labor supply of married women in West Sumatra. This is seen from the probability of husband's income $(X 2)<0.05$. The significant influence of husband's income on the labor supply of married women indicates that labor supply of married women is influenced by the husband's income. This is caused that the increased husband's income will increase the total income of the family so that it will be able to meet family needs, reduce the burden and be able to improve family welfare. If it is later felt the needs of families are met and the burden of the family is reduced, so the married women whose natures as mothers for their children would certainly increase the time for the family (leisure) and reduce working hours so that the labor supply of married women will be reduced. Conversely, when husband's income decreases, it would certainly have an impact on the financial of the family. To overcome this, married woman usually will enter the workforce in order to meet their family needs. Ultimately this situation will increase working hours and labor supply of married women.

Age has a significant negative effect on the labor supply of married women in West Sumatera. This is seen from the probability of age $(\mathrm{X} 3)<0.05$. The significant effect of age on labor supply of married women indicates that the labor supply of married women is affected by age. The higher of age for married women into workforce, the physical condition will decrease and the number of responsibilities such as children will motivate married women to increase their working hours. So this condition will decrease labor supply of married women. Conversely, if married women enter the labor market at a younger age, it will encourage the increase of working hours to be offered. Because at the age, married women don't have much responsibility, the physical condition is still fit and higher spirit will increase the working hours so that the labor supply of married women will increase in the labor market. 
The number of dependents has a significant effect on the labor supply of married women in West Sumatera. This is seen from the probability value of dependents $(X 4)<0.05$. There is a significant influence between the numbers of dependents on the labor supply of married women indicating that the labor supply of married women is influenced by the number of dependents. On the other word, the more number of dependents in a family, the higher the cost for the need of life. If the situation is not accompanied by increased incomes then the welfare of family will decrease. One way to increase family income is to increase the working hours of a wife or married woman. Increased working hours will increase income so that family needs can be got well. Conversely, the small number of dependents family of course will be able to be got the needs of life so it is not force the wife to enter the workforce. Thus, it will decrease working hours and labor supply of married women.

Education has a significant effect on the labor supply of married women in West Sumatra. This is seen from the educational probability value $(X 5)<0.05$. The significant influence of education on labor supply of married women indicates that the labor supply of married women is influenced by education. Education will add insight and knowledge of a person. The higher a person's education will be increased knowledge, insight and skills possessed. People who are educated will have higher motivation to find work because people who are educated will have the higher desirability to realize self-actualization. Self-actualization will make the person in his environment to be recognized, to be respected and increasingly appreciated both from social status and prestige. Thus, this will add the working hours including for married women. Conversely, low education interprets the skills and knowledge possessed also low. The motivation is also usually low, so the desirability to show his self in society is also low. This made him unwilling to increase his working hours due to circumstances to be accepted.

\section{Conclusions}

The results concluded that (1) Wage has a significant and positive effect on the labor supply of married women in West Sumatra. An increase of wages will lead to an increase in the labor supply of married women. (2) Husband's income has a negative effect on the labor supply of married women in West Sumatra. If husband's income increases then the labor supply of married women will decrease. (3) Age has a negative effect to the labor supply of married women in West Sumatra. As age increases, the marriage supply of married women will decrease further. (4) The number of dependents affecting the labor supply of married women in West Sumatra is significant and positive. This means that if the number of dependents increases so the labor supply of married women in West Sumatra will also increase. (5) Education also affects the labor supply of married women in West Sumatra significantly and positively. This means that the higher the education of married women can make the higher of working hours to be offered.

Based on the results of the research, the suggested policies are that the local government should be able to maintain wage stability as reflected from the Provincial Minimum Wage (UMP) and encourage the increasing investment activities. So that it will increase employment and the working hours of the community. Then they launched the Family Planning Program (KB) to the community so that people can plan a better and prosperous family and improve the quality and quantity of education by increasing the education budget for district or city governments in West Sumatra.

\section{References}

Becker, G S. (1976). The Economic Approach to Human Behavior. Links to chapter previews. University of Chicago Press

Becker, G S. (1965). A theory of the allocation of time. Economic Journal, 75 (299), p -493517.

Bellante, D and Jackson, M. (2000). Labor Economics. Translation Edition. Jakarta: FE UI.

Besangko, D. (2010). Microeconomics. United State : John Willey \& Sons Inc.

Blau, FD \& LM Khan. (2016). Changes in the labor supply behavior of married women: 1980-2000. Journal of Labor Economics, 2(1). 61-78. 
Borjas, G J. (2010). Labor Economics. McGraw-Hill Companies, Inc.

Budiman, A. (2005). Division of Labor Sexually. Jakarta: Gramedia.

Carlson, K. (2012). Supply labor of aplication theory and derivatif. Journal of Labor Economics, 14.(1). 45-67.

Danim, S. (2003). Economy and Labor in an Economy. Yogyakarta: Student Literature.

Denilson, R. 2014. Female married and supply labor phenomenon. Journal Research in Labor Economics, 22(1). 31-52.

Djojohadikusumo, S. (2003). Economic Theory and Development Policy. Jakarta: Gramedia.

Eliana, N. (2007). Factors affecting women work time intensity at PT agricinal. Journal of Applied Economics, 9(2). 78-87.

Kartasasmita, G.(2006). Community Empowerment: The Concept of Development Rooted in Society. Jakarta: Bappenas.

Kusumowindo, S. (2001). Labor Force: In Demographic Basics. Jakarta: Demography Institute of FE UI.

Laswell, M. (2005). Marriage \& The Family. California : Wadsworth Pub.

Mincer, J.(2016). Labor force participation of married woman : a study of labor supply. International Journal of Economic, Bussines and Accounting Research, 3(4). 51-67.

Minh, T. (2008). Supply labor interaction and determinant. International Journal of Economics and Management, 3(2), 221-240.

Nilakusumawati. (2010). Determinant women working. Journal of Economics and Development Studies, 2 (1), Thing: 77-92.

Parkinson, A. (2012). Fertility and maternal labor supply in vietnam: Conflicting Policy Goals?. Journal of the Japanese and International Economies, 38 (2), Pages 52-72.

Subri, M. (2003). Human Resource Economics. Jakarta: PT Raja Grafindo Persada.

Sumartoyo, SR. (2002). Employment of Women. Yogyakarta: Graha Ilmu.

Suparmoko. (2002). Human Resource Economics. Yogyakarta: Andi Yogyakarta.

Zehra, M. (2008). Women and the World of Work. Jakarta: Ghalia. 